\title{
Spawning behaviour and mating success in hybrids of silver bream (Blicca bjoerkna L.) and rudd (Scardinius erythrophthalmus $\mathrm{L}_{\text {.) }}$ in an experimental environment
}

\author{
Billy Nzau Matondo ${ }^{1, *}$, Michaël Ovidio ${ }^{1}$, Jean Claude Philippart ${ }^{1}$ and Pascal Poncin $^{2}$ \\ ${ }^{1}$ University of Liège, Biology of Behaviour Unit, Laboratory of Fish Demography and \\ Hydroecology, 10 Chemin de la Justice, B-4500 TIHANGE, Belgium \\ ${ }^{2}$ University of Liège, Biology of Behaviour Unit, Laboratory of Fish Ethology, \\ 22 Quai Van Beneden, B-4020 Liège, Belgium
}

Submitted: April 8, 2012. Final revision received: July 31, 2012. Accepted: August 5, 2012

\begin{abstract}
The egg-release, mating, courting and aggressive acts for the spawning behaviour as well as the survival rates after spawning at stages of eyed embryos, viable hatchlings, and larvae to dry food consumption for the mating success were studied in cultured silver bream Blicca bjoerkna $\times$ rudd Scardinius erythrophthalmus hybrids at their first sexual maturity. Experiments were conducted in experimental environments simulating natural reproductive conditions of the parental species. Spawning behaviour was analysed over 1 day from 8.00 to 18.00 hours using a remote-controlled video. Mating success was assessed from eggs and hatched embryos collected on the spawning ground. The results showed that these hybrids exhibited all the reproductive behaviours of the parental species with significantly more courtship than mating. Each egg-release act was accompanied by mating behaviour, involving all the experimental males. A surprising aggressive behaviour was observed in one male which attacked all other experimental fish. Successful mating resulted in the presence of fertilized eggs, the production of hatched embryos in experiments, and the survival of larvae at the dry food consumption stage. However, the low viable hatchling rate observed could indicate a very low chance of survival for these hybrids in rivers in which the occurrence of post-F1 individuals may be more possible by backcrossing.
\end{abstract}

\section{Keywords}

Spawning behaviour; mating success; hybrids; fish

*) Corresponding author; e-mail: bnmatondo@ulg.ac.be 


\section{Introduction}

Silver bream, Blicca bjoerkna (L), and rudd, Scardinius erythrophthalmus (L), are two native European cyprinid fish species belonging to the same Leuciscinae subfamily (Bianco et al., 2001; Perea et al., 2010). As nearly all Leuciscinae genera, these two species possess a nearly invariable diploid chromosome number $(2 \mathrm{n}=$ 50) with extremely uniform karyotypes (Rab and Collares-Pereira, 1995; Bianco et al., 2004; Rab et al., 2008). Both species, silver bream and rudd, are gregarious fish, live in sympatry in the same type of river and reproduce from May to July (Philippart and Vranken, 1983; Philippart, 1989; Van Den Berg et al., 1994; Pflieger, 1997; Kottelat and Freyhof, 2007).

The reproductive strategy of both silver bream and rudd has already been studied and described as polygamous and phytophilous, without parental care (Svardson, 1949; Poncin, 1996; Kottelat, 1997; Jurajda et al., 2004). Poncin et al. (2010) have observed males of silver bream expressing a high level of courtship with numerous tactile stimulations of the female during the spawning period. Several authors have reported that these two fish species exhibit non-aggressive and non-territorial tactics during the breeding season (Svardson, 1949; Spivak, 1987; Haberlehner, 1988; Poncin et al., 2010). However, Breder and Rosen (1966) have reported that contrary to silver bream, during the spawning period rudd males defended territories including plants on which the adhesive eggs were deposited, and males continued to discharge sperm for some time after the eggs were deposited. Numerous biological similarities mentioned above are, however, factors favouring the natural hybridization process between silver bream and rudd in river environments.

In Lake Vansjoe in Norway, Pethon (1981) collected 356 cyprinid fish in which four fish were natural hybrids of silver bream $\times$ rudd. Otherwise, very few data have been reported in the literature on the capture of these hybrids in rivers (Slastenenko, 1957; Swinney and Coles, 1982; Treer and Kolak, 1994; Kottelat, 1997). This demonstrates that silver bream $\times$ rudd hybrids are much less frequent in rivers, but their existence in rivers is increasing interest in gaining better knowledge of these hybrids in all aspects of biology including their reproductive behaviour and mating success. As for hybrids that are more frequent in rivers, in these rare hybrids, the two biological aspects often remain largely unknown regarding the considerable knowledge amassed for identifying natural hybrids. Investigating the reproductive behaviour and mating success of the hybrids might increase the knowledge on the viability of these under-studied individuals, and thus, on their potential ecological impact.

This study therefore aimed to simulate the natural reproduction conditions of cyprinid fish in the laboratory to analyse the reproductive performance of cultured silver bream $\times$ rudd hybrids at their first sexual maturity with the following specific objectives: 
(i) To evaluate the reproductive behaviour capacity of these hybrids in terms of egg release, mating, courting and aggressive acts under reproductive conditions between hybrids, without hormonal injections;

(ii) To estimate the mating success by quantifying, after spawning, the survival rate at the eyed-embryo and hatching stages from eggs collected in spawning grounds, and the survival rate of larvae at the dry food consumption stage from hatched embryos produced in behavioural experiments.

\section{Material and methods}

\section{Production of hybrids}

The silver bream $\times$ rudd hybrids used in this study were produced by interspecificcrossing made from a silver bream female specimen (Fork length, weight: $265 \mathrm{~mm}$, $340 \mathrm{~g})$ and a specimen of rudd male $(340 \mathrm{~mm}, 1010 \mathrm{~g})$ captured in the fish pass at the Lixhe dam (Belgian Meuse River, $50^{\circ} 45^{\prime} \mathrm{N} ; 5^{\circ} 40^{\prime} \mathrm{E}$ ) during their reproductive season in spring 2003, and were morphologically identified following the descriptions made by Spillman (1961). These hybrids were reared at $20^{\circ} \mathrm{C}$ in $1.04 \times 1.04 \times$ 0.41-m basins connected to a recirculating system equipped with a biofilter at the Tihange Aquaculture Station in Belgium. According to Nzau Matondo et al. (2011), hybrid fish were fed with Artemia nauplii (50\% protein at dry base) for the first 2 weeks after hatching, then with a mixture of Artemia and Nippaï dry food (Lucky Star, Taiwan 54\% protein) for the following 2 weeks, and thereafter with Nutra dry food (Skretting Trow, France 52\% protein) only. The hybrids reached sexual maturity after 24 months.

\section{Behavioural observation}

Experiments were conducted in May 2005, using two identical reproductive experiments: a $0.92 \times 0.40 \times 0.40$-m experimental nylon basket installed in a $6.00 \times$ $1.00 \times 0.67-\mathrm{m}$ tank which was attached to a recirculating system equipped with a biofilter. Each experiment was equipped with an aerator for aeration and a $0.16 \times 0.16-\mathrm{m}$ synthetic spawning ground imitating vegetation. A female hybrid was placed to reproduce with three corresponding hybrid males the day before the fish behaviour was recorded. They were characterized by sex and size (table 1). These hybrid fish were maintained at a water temperature of $20 \pm 0.3^{\circ} \mathrm{C}, 8.0 \pm$ $0.5 \mathrm{mg} / \mathrm{l}$ dissolved oxygen, $\mathrm{pH} 7.7 \pm 0.4$, water replacement rate 5 renewals $/ \mathrm{h}$, and the photoperiod was set at $16 \mathrm{~h}$ of light and $8 \mathrm{~h}$ of darkness, matching the optimal spawning conditions of these species in natural environments (Herzig and Winkler, 1986; Tarkan, 2006). These hybrid fish were not fed during the experiment. This experimental protocol was performed according to Nzau Matondo et al. (2008a, 2011).

The number of egg-release, mating, courting and aggressive acts as well as the participation of males in mating were analysed over 1 day from 8.00 to $18.00 \mathrm{~h}$, cor- 
Table 1.

Fork length and weight frequency of hybrid fish used in reproductive experiments.

\begin{tabular}{lcc}
\hline 1 1 SR $\times 30^{\top} \mathrm{SR}$ & Experiment 1 & Experiment 2 \\
\cline { 2 - 3 } & Fork length $(\mathrm{mm}) /$ weight $(\mathrm{g})$ & Fork length $(\mathrm{mm}) /$ weight $(\mathrm{g})$ \\
\hline P & $142 / 60$ & $162 / 60$ \\
$\mathrm{~A}$ & $152 / 55$ & $135 / 38$ \\
$\mathrm{~B}$ & $126 / 35$ & $128 / 35$ \\
$\mathrm{C}$ & $125 / 30$ & $130 / 32$ \\
\hline
\end{tabular}

Abbreviations and symbols: A, B, C, male hybrid fish; SR, F1 hybrid of silver bream $\times$ rudd; $\sigma^{2}$, male; , female.

responding to the beginning and end of spawning activity, using a remote-controlled video system (Nzau Matondo et al., 2011). Mating was defined as sexual contact between fish of the opposite sex followed by expulsion of gametes. Spawning was defined as the release of eggs by a female. Release of eggs and sperm was indicated by trembling and violent splashing movements on the spawning ground (Nzau Matondo et al., 2010). A courting act was expressed as the behaviour of one or more males positioned as close to a female as possible (at its side or behind) for reproduction, with forehead swimming and tactile stimulation on the sides and abdomen of the female (Poncin et al., 2010). Aggressive behaviour was defined as the brutal attack of a fish by another fish. The number of egg-release, mating, courting and aggressive acts were counted hourly. Figure 2, illustrating spawning and tactile courting acts was drawn by hand from video camera images and visual observation of the fish.

\section{Mating success}

Mating success was assessed after spawning and was expressed as the survival rate at the following developmental stages: eyed embryos, viable hatchlings, and larvae to dry food consumption. The percentage of eyed embryos one day after spawning was evaluated from two samples of 100 eggs collected on the spawning ground for each experiment, using a microscope. The viable hatchling rate was estimated three days post-spawning from two samples of 100 eggs sampled from the spawning ground at the eyed-embryo stage for each experiment and placed in a $0.15 \times 0.13 \times$ $0.10-\mathrm{m}$ experimental nylon basket floating in experimental environments.

The survival rate of larvae to dry food consumption (5 weeks old) was evaluated from two samples of 30 hatched embryos collected from each experiment and placed in a $0.15 \times 0.13 \times 0.10$-m experimental nylon basket floating in a $0.92 \times$ $0.40 \times 0.40$-m experimental nylon basket installed in the same tank with experimental environments and reared at $20 \pm 0.5^{\circ} \mathrm{C}, 8.3 \pm 0.3 \mathrm{mg} / \mathrm{l}$ dissolved oxygen, $8.0 \pm 0.3 \mathrm{pH}$ and a $16 \mathrm{~L} / 8 \mathrm{~N}$ photoperiod, with $0.02 \pm 0.5$ and $0.29 \pm 0.7 \mathrm{mg} / \mathrm{l}$ for nitrite and ammonium. Larvae were fed exclusively with Artemia nauplii (50\% pro- 
tein at dry base) for the first 2 weeks after hatching, then with a mixture of Artemia and dry food (54\% protein) for the following 2 weeks, and thereafter with dry food (52\% protein) only. Daily food was readjusted weekly as per fish biomass.

\section{Data analysis}

The comparison of spawning activities and differences between males in the participation in mating, courting and aggressive acts were analysed with the KruskalWallis (KW) test followed by the Mann-Whitney U test. The Spearman rank correlation was used to assess the relationships between spawning activities. Fisher's exact probability (FEP) test was used to compare relative frequencies of the male participation in mating and survival rates between different developmental stages. For all statistical analyses, a probability level of $P<0.05$ was considered significant.

\section{Results}

\section{Spawning behaviour}

In this study, egg release and mating activities were observed in all reproductive experiments between silver bream $\times$ rudd hybrids. Each egg-release act was accompanied by a mating act. These two activities in these hybrids only occurred on the spawning ground, with the same number for each (fig. 1), for a mean of 27 for egg-release and mating acts.

a

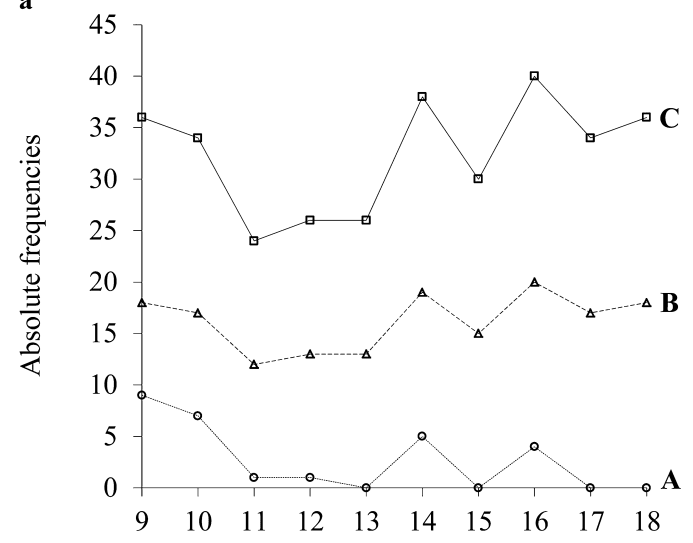

Time (hours)

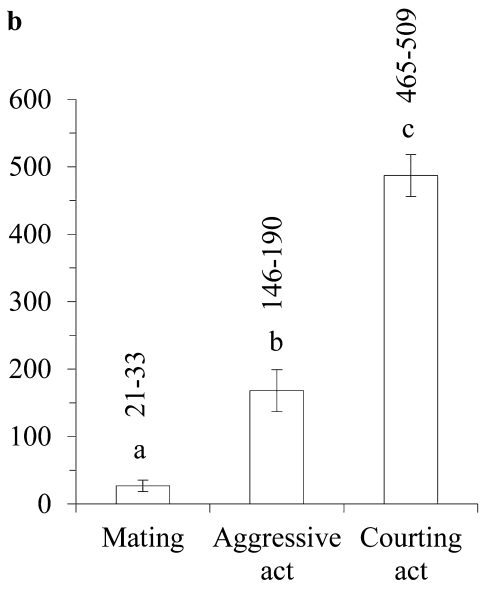

Spawning behaviour

Figure 1. Spawning behaviours (a) and their levels (b) in reproductive experiments between hybrids from 8.00 to $18.00 \mathrm{~h}$. A, Mating or egg-release; B, aggressive behaviour and C, courting act. Mean, standard deviation and range values of two behavioural experiments. Bars sharing at least one common script are not significantly different, whereas other comparisons differ at $P<0.05$ (Mann-Whitney U test). 


\section{Table 2.}

Spearman rank correlation coefficients for the relationships between mating, aggressive behaviour and courting act in reproductive experiments between hybrids from 8.00 to $18.00 \mathrm{~h}$.

\begin{tabular}{lccc}
\hline Relationship & $N$ & $r_{S}$ & $P$ \\
\hline Mating/Attack & 10 & 0.43 & 0.1967 \\
Mating/Courting & 10 & 0.43 & 0.1967 \\
Attack/Courting & 10 & 1.00 & 0.0027 \\
\hline
\end{tabular}

Abbreviations: $N$, sample size; $P$, probability level; $r_{s}$, Spearman rank correlation coefficient.

The results of the spawning activities in the reproductive experiments between hybrids are summarized in fig. 1a. The behaviours show the same trend: the mating act arises with increasing aggression and courting activity. The Kruskal-Wallis test revealed that the level of each activity differed significantly $(d f=2, H=25.806$, $P<0.0001)$ between behaviours. The Mann-Whitney U-test showed that mating activity (mean value, 27 matings) was substantially lower $(U=0, N=10$, $P=0.0001)$ than aggressive behaviour (168 attacks), which was also significantly lower (U test: $U=0, N=10, P=0.0002$ ) than courting acts (480 courting acts) (fig. 1b). The study of the relationships between mating, aggressive and courting acts (table 2) revealed no significant correlations (Spearman rank correlation: $r_{s}=0.273, N=10, P=0.1214$ ) for both the relation between mating acts and aggressive acts, and the relation between mating acts and courting acts. However, for the relation between aggressive acts and courting acts, it was observed that the number of attacks correlated well with the number of courting acts (Spearman rank correlation: $\left.r_{s}=1.0, N=10, P=0.0027\right)$.

A female hybrid mated simultaneously and successively with its three corresponding hybrid males (table 3). Mating combinations of the female and one male,

Table 3.

Males participating in mating in reproductive experiments between hybrids from 08.00 to $18.00 \mathrm{~h}$.

\begin{tabular}{lcccc}
\hline \multirow{1}{*}{$\mathrm{SRR} \times 30^{\top} \mathrm{SR}$} & \multicolumn{3}{c}{ Mating (numbers) } & \multirow{2}{*}{ Relative frequencies (\%) } \\
\cline { 2 - 4 } Participating males & Mean & Standard deviation & Range & \\
\hline $\mathrm{A}$ & 10 & 4.2 & $7-13$ & $37.0^{\mathrm{bc}}$ \\
$\mathrm{B}$ & 1 & 1.4 & $0-2$ & $3.7^{\mathrm{a}}$ \\
$\mathrm{C}$ & 1 & 1.4 & $0-2$ & $3.7^{\mathrm{a}}$ \\
$\mathrm{A}+\mathrm{B}$ & 3 & 1.4 & $2-4$ & $11.1^{\mathrm{ab}}$ \\
$\mathrm{A}+\mathrm{B}+\mathrm{C}$ & 12 & 7.1 & $7-17$ & $44.5^{\mathrm{c}}$ \\
\hline
\end{tabular}

Abbreviations and symbols: A, B, C, male hybrid fish; mean, standard deviation and range values of two behavioural experiments; SR, F1 hybrid of silver bream $\times$ rudd; $\sigma^{x}$, male; , female. Relative frequencies with a common superscript in the column do not differ significantly (Fisher's exact probability FEP test, $P<0.05)$. 

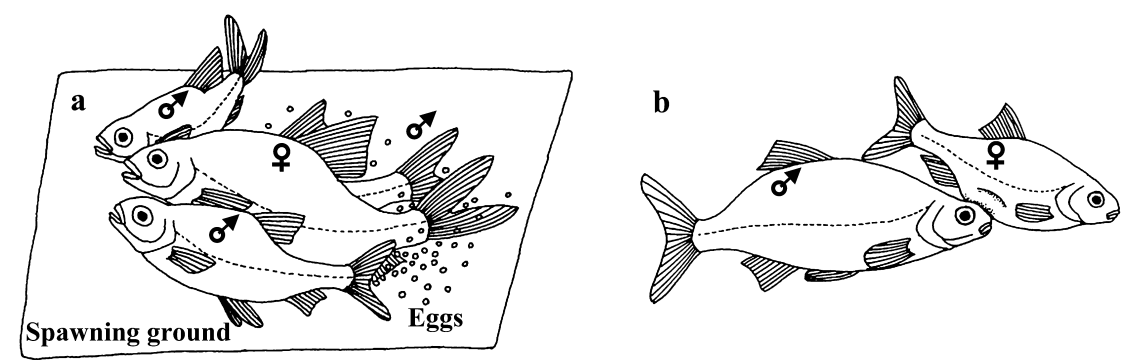

Figure 2. A spawning act of the female and its three males (a), and a tactile courting act of the male A in reproductive experiments between hybrids. Symbols: $\sigma^{x}$, male; $q$, female.

and the female and its three males were most frequently observed, accounting for $37 \%$ and $44.5 \%$ of the total mating acts, respectively. No significant difference was found between these two combinations, but the combination of the female and its three males (fig. 2a) was significantly higher (Fisher's exact probability test: $P<0.05)$ than the other male combinations. For the individual participation of the male in mating, a significantly higher participation (FEP test: $P<0.01$ ) was observed in male A.

For aggressive behaviour, only one male displayed aggressive behaviour and attacked every other experimental fish (fig. 3a). The fish combination significantly affected the frequency of aggressive interactions (Kruskal-Wallis test: $d f=2$, $H=12.614, P=0.0018$ ). The attacks on the hybrid male B by the hybrid male A clearly predominated (Mann-Whitney U test: $U=33, N=10$ and 20, $P=0.0032$ )
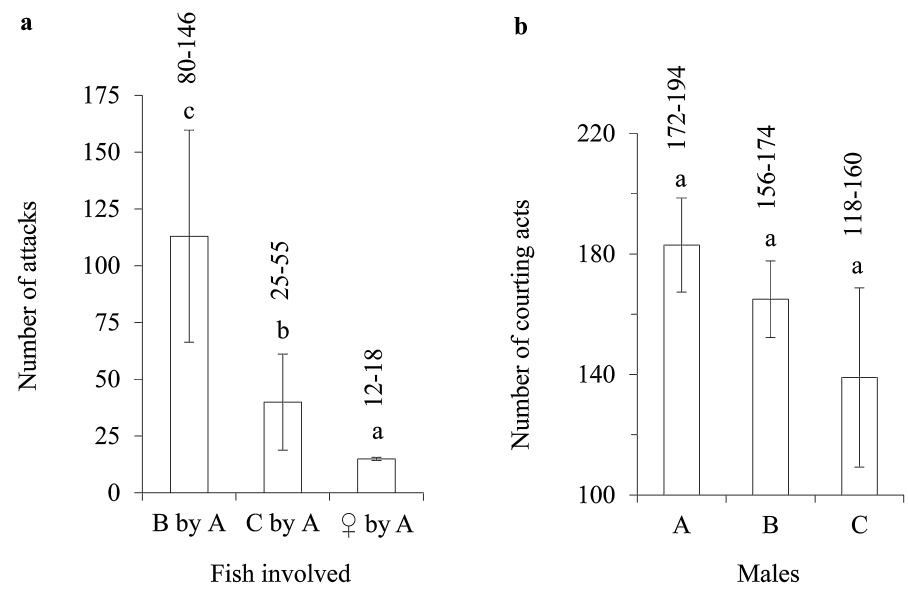

Figure 3. Levels of attack and courting acts for each experimental male in reproductive experiments between hybrids from 8.00 to $18.00 \mathrm{~h}$. Mean, standard deviation and range values of two behavioural experiments; o, female; A, B, C, male hybrid fish; B by A indicates the male B is the victim of the aggression from the male $\mathrm{A}$. Bars sharing at least one common script are not significantly different, whereas other comparisons differ at $P<0.05$ (Mann-Whitney U test). 


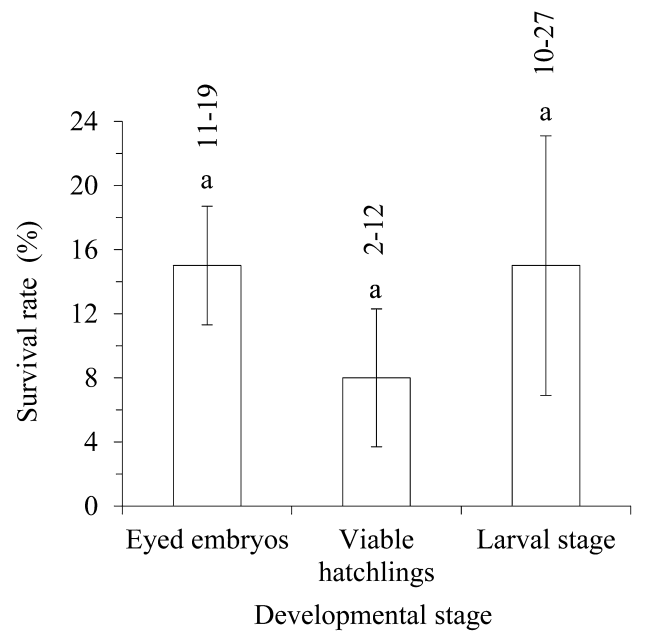

Figure 4. Mating success in reproductive experiments between hybrids. Mean, standard deviation and range values for four observations in two replications in each experiment at each developmental stage; bars sharing at least one common script are not significantly different, whereas other comparisons differ at $P<0.05$ (Fisher's exact probability test).

over all other aggressions and were twice as numerous as all other aggressions. The female was also attacked, but this was the least frequent aggressive act observed.

Comparative courting acts (fig. $3 \mathrm{~b}$ ) revealed no significant effect of experimental males (Kruskal-Wallis test: $d f=2, H=1.263, P=0.5319)$. However, the highest level of courting activity was found in male A (fig. 2b), accounting for a mean value of 183 courting acts versus 139 and 165 for the males C and B, respectively.

\section{Mating success}

The study of survival rates at the early developmental stages (fig. 4) showed that after spawning in experiments, the survival rate was found to be very low at the hatching stage, with a mean value of $8 \%$ versus $15 \%$ for both eyed-embryo and larval stages. The larval stage showed the highest survival rate of $27 \%$ versus 12 and $19 \%$ for hatching and eyed-embryo stages, respectively. The lowest survival was observed in the hatching stage, accounting for $2 \%$ versus 10 and $11 \%$ for larval and eyed-embryo stages, respectively, but no significant difference in survival rates (FEP test: $P>0.05$ ) was observed between these stages.

Survival curves calculated from mean survival of eyed-embryo, hatching and larval stages $(15 \% \times 0.08 \times 0.15)$ showed a very low survival rate $(0.18 \%)$ at the larval to dry food consumption stages.

\section{Discussion}

\section{Spawning behaviour}

The study of reproductive behaviour of silver bream $\times$ rudd hybrids has revealed that males and females of these hybrids are biologically viable. These hybrids have 
the capacity to reproduce between hybrid individuals and to exhibit typical reproductive behaviour such as egg release, mating and courtship, as observed in the wild population of parental species, the silver bream (Spivak, 1987) and the rudd (Svardson, 1949). However, a surprising behaviour, acts of aggression, was observed between hybrid fish, even though in this study hybrids were produced from parental species, the silver bream and the rudd, recognized as being non-aggressive and non-territorial. This aggressive behaviour was expressed in each experiment by one male which attacked all other experimental fish. This atypical behaviour could be a strategy on the part of this male refusing to share the only experimental female with other males. This hypothesis seems to hold in relation to the involvement of this same male in all matings, the high level of courting acts for each experimental male, and the high significant relationship found between courtship and aggressive activity. More courtship than aggressive acts and courtship exhibited by all males versus aggression by only one male both confirm the peaceful nature of the parental species. The unusual aggressive behaviour was also observed in these hybrids on the part of a 1-year-old and was used for the defense of the single feeding place in the rearing basin. For Haberlehner (1988), the rudd can rarely display inter- and intraspecific aggression during feeding.

Each egg-release activity accompanied by a mating act in these hybrids is a commonly encountered situation among the parental species (Svardson, 1949; Poncin et al., 2010). This proves a high level of viability and sexual activity for these hybrids as indicated by the presence of fertilized eggs, and thus effective fertility of male and female hybrids, and by the intense courtship and attack activity characterizing the spawning period. The female ready to release eggs moved to the spawning substrate, and in a successful spawning act, female and males with gaping mouths and pectoral fins deployed, released eggs and sperm in a twisting movement of the body signaled by trembling movements and violent splashing. Spawning takes place only on spawning substrate, confirming the phytophilous of the parental species (Philippart and Vranken, 1983; Nzau Matondo et al., 2009). The mating combination of the female hybrid and its three corresponding males most frequently observed, indicates that these hybrids have a polyandrous mating system which could give as in no hybrids fish species many advantages useful for the survival of offspring such as high fertility, prevention of inbreeding and maintenance genetic diversity (Kellogg et al., 1998; Arnqvist and Nilsson, 2000; Becher and Magurran, 2004; Ivy and Sakaluk, 2005). This mating system corresponds to that of the parental species (Svardson, 1949; Poncin et al., 2010) and other no hybrids fish species belonging to the Cyprinidae family and other families (Goto, 1987; Kodric-Brown, 1995; Maclnnis and Corkum, 2000).

\section{Mating success}

In this study, successful mating between hybrids observed in reproductive experiments resulted in the presence of fertilized eggs and particularly in the production of hatched embryos from the reproductive experiments, which simulated natural 
conditions of parental species reproduction using a spawning ground, high temperature, mixing of the sexes, natural photoperiod, egg incubation on the spawning substrate and no hormonal injections. Similar reproductive success in hybrids has already been observed in our previous experiments conducted on other cultured hybrids of cyprinid fish such as roach Rutilus ritulus $\times$ silver bream (Nzau Matondo et al., 2008a), roach $\times$ common bream Abramis brama (Nzau Matondo et al., 2011) and silver bream $\times$ common bream (Nzau Matondo et al., 2008b), determined by the presence of fertilized eggs after matings. However, the production of hatched embryos and their breeding is an original feature of this behavioural study.

The eyed-embryo rate observed was very low considering the high egg survival (>90\%), already reported in natural environments from freshwater fish species spawning in vegetation (Franklin and Smith, 1963; Nikolskii, 1969; Clady, 1975). This might suggest the problem of gamete quality in hybrids. As already announced by Jobling et al. (2002), fertilization success depends on the quality (and quantity) of both male and female gametes.

In this study, the progression of survival from fertilization to larvae to the dry food consumption stage revealed a low survival rate $(<0.5 \%)$, indicating a very small chance for $\mathrm{F} 2$ offspring of silver bream $\times$ rudd hybrids occurring in rivers. Most particularly, compared to our experiments and according to Nzau Matondo et al. (2007), rivers are characterized by fluctuating environmental conditions which can substantially affect fish survival.

The present data collected from conditions simulating the natural environment provide evidence of the biological viability of cultured silver bream $\times$ rudd hybrids in terms of reproductive behaviour and fertility of hybrids. These hybrids are fertile, can reproduce among themselves without human assistance, and can exhibit all the reproductive behaviours of the parental species, including aggressive behaviour. However, the very low rate of survival at hatching is a bottleneck for the propagation of the F2 generation in the natural stock of parental species populations. The occurrence of post-F1 individuals in the natural stock of parents could be ecologically more possible by means of backcrossing.

\section{Acknowledgements}

We thank G. Rimbaud and Y. Neus for their continued technical assistance during the experiments, and A.M. Massin for his unending co-operation while drawing diagrams presented in this study. This research was supported by F.R.F.C. grants No. 1482 and 1.5.120.04.

\section{References}

Arnqvist, G. \& Nilsson, T. (2000) The evolution of polyandry: multiple mating and female fitness in insects. Anim. Behav., 60, 145-164.

Becher, S.A. \& Magurran, A.E. (2004) Multiple mating and reproductive skew in Trinidadian guppies. Proc. R. Soc. London, Ser. B: Biol. Sci., 271, 1009-1014. 
Bianco, P.G., Ketmaier, V. \& Bussato, T. (2001) Approccio multidisciplinare all'analisi tassonomica del genere Scardinius (Cyprinidae) en Europa. Quaderni ETP, 30, 115-120.

Bianco, P.G., Aprea, G., Balleto, E., Capriglione, T., Fulgione, D. \& Odierna, G. (2004) The karyology of the cyprinid genera Scardinius and Rutilus in Southern Europe. Ichthyol. Res., 51, 274-278.

Breder, C.M. Jr. \& Rosen, D.E. (1966) Modes of Reproduction in Fishes. T. F. H. Publications, Jersey City, $941 \mathrm{pp}$.

Clady, M.D. (1975) Early survival and recruitment of smallmouth bass in northern Michigan. J. Wildl. Manage., 39, 194-200.

Franklin, D.R. \& Smith, L.L. Jr. (1963) Early life history of the northern pike. Esox lucius L., with special reference to the factors influencing the numerical strength of year classes. Trans. Am. Fish. Soc., 92, 91-110.

Goto, A. (1987) Polygyny in the river sculpin, Cottus hangiongensis (Pisces: Cottidae), with special reference to male mating success. Copeia, 1, 32-40.

Haberlehner, E. (1988) Comparative analysis of feeding and schooling behaviour of the Cyprinidae Alburnus alburnus (L., 1758), Rutilus rutilus (L., 1758), and Scardinius erythrophthalmus (L., 1758) in a Backwater of the Danube near Vienna. Intern. Revue Hydrobiol. Hydrogr., 75, 537-546.

Herzig, A. \& Winkler, H. (1986) The influence of temperature on the embryonic development of three cyprinid fishes, Abramis brama, Chalcalburnus chalcoides mento and Vimba vimba. J. Fish Biol., 28, 171-181.

Ivy, T.M. \& Sakaluk, S.K. (2005) Polyandry promotes enhanced offspring survival in decorated crickets. Evolution, 59, 152-159.

Jobling, S., Coey, S., Whitmore, J.G., Kime, D.E., Van Look, K.J.W., McAllister, B.G., Beresford, N., Henshaw, A.C., Brighty, G., Tyler, C.R. \& Sumpter, J.P. (2002) Wild intersex roach (Rutilus rutilus) have reduced fertility. Biol. Reprod., 67, 515-524.

Jurajda, P., Ondrac Kova, M. \& Reichard, M. (2004) Managed flooding as a tool for supporting natural fish reproduction in man-made lentic water bodies. Fisheries Manag. Ecol., 11, 237-242.

Kellogg, K.A., Markert, J.A., Stauffer, J.R. \& Kocher, T.D. (1998) Intraspecific brood mixing and reduced polyandry in a maternal mouth-brooding cichlid. Behav. Ecol., 9, 309-312.

Kodric-Brown, A. (1995) Does past reproductive history predict competitive interactions and male mating success in pupfish? Anim. Behav., 50, 1433-1440.

Kottelat, M. (1997) European freshwater fishes. Biologia, 52, 1-271.

Kottelat, M. \& Freyhof, J. (2007) Handbook of European freshwater fishes. Publications Kottelat, Cornol, Switzerland, $646 \mathrm{pp}$.

Maclnnis, A.J. \& Corkum, L.D. (2000) Age and growth of round goby Neogobius melanostomus in the Upper Detroit River. Trans. Am. Fish. Soc., 129, 852-858.

Nikolskii, G.V. (1969) Theory of fish population dynamics. Olever and Boyd, Edinb, 323 pp.

Nzau Matondo, B., Ovidio, M., Poncin, P., Kakesa, T.A., Wamuini, L.S. \& Philippart, J.C. (2007) Hybridization success of three common European cyprinid species, Rutilus rutilus, Blicca bjoerkna and Abramis brama and larval resistance to stress. Fisheries Sci., 73, 1136-1145.

Nzau Matondo, B., Ovidio, M., Philippart, J.C. \& Poncin, P. (2008a) Mating patterns of firstgeneration hybrids of the roach, Rutilus rutilus (L.), and the silver bream, Blicca bjoerkna (L.). J. Ethol., 26, 179-183.

Nzau Matondo, B., Ovidio, M., Philippart, J.C. \& Poncin, P. (2008b) Sexual maturity, reproductive behaviour and fertility in the first-generation hybrids of Blicca bjoerkna (L.) $\times$ Abramis brama $\mathrm{L}$. Cybium, 32, 286-289. 
Nzau Matondo, B., Ovidio, M., Philippart, J.C. \& Poncin, P. (2009) Hybridization behaviour between two common European cyprinid fish species - silver bream, Blicca bjoerkna and common bream, Abramis brama - in a controlled environment. Anim. Biol., 59, 97-108.

Nzau Matondo, B., Ovidio, M., Poncin, P. \& Philippart, J.C. (2010) Eco-ethological characteristcs of two natural hybrids of Abramis brama (L.) of the River Meuse basin. Environ. Biotech., 6, 42-52.

Nzau Matondo, B., Ovidio, M., Philippart, J.C. \& Poncin, P. (2011) Reproductive behaviour and sexual production in the first-generation hybrids of roach Rutilus rutilus $\mathrm{L} . \times$ common bream Abramis brama L. J. Appl. Ichthyol., 27, 859-867.

Perea, S., Böhme, M., Zupančič, P., Freyhof, J., Šanda, R., Müfit Özuluğ, M., Abdoli, A. \& Doadrio, I. (2010) Phylogenetic relationships and biogeographical patterns in Circum-Mediterranean subfamily Leuciscinae (Teleostei, Cyprinidae) inferred from both mitochondrial and nuclear data. BMC Evol. Biol., 10, 265-292.

Pethon, P. (1981) Four natural cyprinid hybrids recorded from Lake Vansjoe, SE Norway. Fauna Norvegica, 2, 28-33.

Pflieger, W.L. (1997) The Fishes of Missouri. Missouri Department of Conservation, Jefferson City, $372 \mathrm{pp}$.

Philippart, J.C. \& Vranken, M. (1983) Atlas des poissons de Wallonie. Distribution, Ecologie, Ethologie, Pêche, Conservation. Cah. Ethol. Appl., 3, 395 pp.

Philippart, J.C. (1989) Ecologie des populations de poissons et caractéristiques physiques et chimiques des rivières dans le bassin de la Meuse belge. B. Soc. Géog. Liège, 25, 175-198.

Poncin, P. (1996) Reproduction chez nos poissons. Fédération Sportive des Pêcheurs Francophones de Belgique Ed. Nelles Imprimeries, Havaux, 96 pp.

Poncin, P., Termol, C., Nzau Matondo, B., Philippart, J.C. \& Kestemont, P. (2010) Behavioural study of polyandrous spawning in Blicca bjoerkna under a controlled environment. Folia Zool., 59, 257 266.

Rab, P. \& Collares-Pereira, M.J. (1995) Chromosomes of European cyprinid fishes (Cyprinidae, Cypriniformes): a review. Folia Zool., 44, 193-214.

Rab, P., Rabova, M., Pereira, C.S., Collares-Pereira, J.M. \& Pelikanova, S. (2008) Chromosome studies of European cyprinid fishes: interspecific homology of leuciscine cytotaxonomic marker-the largest subtelocentric chromosome pair as revealed by cross-species painting. Biol. Sci., 16(6), 863-873.

Slastenenko, E. (1957) A list of natural fish hybrids of the World. Hydrobiol Series B, 4(2-3), 76-97.

Spillman, C.J. (1961) Faune de France, $n^{\circ}$ 65. Poissons d'eau douce Paul Le Chevalier, Paris, 303 pp.

Spivak, E.G. (1987) Peculiarities of reproduction of white bream, Blicca bjoerkna, in Bys of Kakhovka Reservoir. Vopr. Ichtiol., 1, 101-105.

Svardson, G. (1949) Note on spawning habitats of Leuciscus erythrophthalmus (L.), Abramis brama (L.) and Esox lucius (L.). Rept. Inst. Freshwat. Res. Drottningholm, 33, 197-203.

Swinney, G.N. \& Coles, T.F. (1982) Description of two hybrids involving silver bream, Blicca bjoerkna (L.) from British waters. J. Fish. Biol., 20, 121-129.

Tarkan, A.S. (2006) Reproductive ecology of two cyprinid fishes in an oligotrophic lake near the southern limits of their distribution range. Ecol. Freshw. Fish., 15(2), 131-138.

Treer, T. \& Kolak, A. (1994) The research in fish genetics in Croatia former Yugoslavia. Ribarstvo, 52(1), 17-31.

Van Den Berg, C., Van Snik, G.J.M., Van Den Boogaart, J.G.M., Sibbing, F.A. \& Osse, J.W. (1994) Comparative microanatomy of the branchial sieve in three sympatric cyprinid species, related to filter-feeding mechanisms. J. Morphol., 219, 73-87. 